\title{
$\mathrm{L}_{2}$ Listening Comprehension:
}

\section{Is it a Language Problem or Listening Problem?}

\author{
Mostafa El-dali ${ }^{1}, \mathrm{PhD}$. \\ ${ }^{1}$ Department of Linguistics, College of Humanities \& Social Sciences, United Arab Emirates University, Al-Ain, \\ UAE, 15551 \\ Correspondence: Mostafa El-dali, PhD., Department of Linguistics, College of Humanities \& Social Sciences, \\ United Arab Emirates University, Al-Ain, UAE, 15551
}

Received: September 17, 2015

Accepted: November 2, 2016

Online Published: January 23, 2017, 2017

doi:10.5430/elr.v6n1p14

URL: http://dx.doi.org/10.5430/elr.v6n1p14

\begin{abstract}
In a foreign language environment, students typically have limited exposure to the language outside formal classrooms. Therefore, their ability to comprehend spoken English may be limited. To add to this problem, $\mathrm{L}_{2}$ learners often regard listening as the most difficult language skill to learn. On the other hand, it is noticeable that $\mathrm{L}_{2}$ listening remains the least researched of all four language skills. Accordingly, the present study is based on the commonly believed premises that (1) investigating the listening comprehension process can provide useful insights into teaching listening and (2) learners who learn to control their listening process can enhance their comprehension, and their overall proficiency may be highly developed.

The present study reports on the results of an empirical study on forty-six $\mathrm{L}_{2}$ learners of English. The subjects were equally divided into two groups. The first group ( $\mathrm{N}=23$ ) represents first year students (Beginners) in the Department of English at the Faculty of Education, Menufia University, Egypt. The second group ( $\mathrm{N}=23)$ represents fourth year students (Advanced) in the same department. The major question that this study attempts to answer is "whether listening comprehension a language problem or listening problem?" The instruments of this study consist of five tasks: pre-test, questionnaire, classroom instruction sessions, post-test, and interviews. The data analysis had a quantitative and a qualitative part. Results were obtained and conclusions were made.
\end{abstract}

Keywords: $\mathrm{L}_{2}$ listening comprehension, Language problem, Listening problem

\section{Introduction}

In a foreign language environment, students typically learn English through formal classroom instruction and have limited exposure to the language outside formal study. In such circumstances, their ability to comprehend spoken English may be limited (Chang, 2008; Kim, 2006; Huang, 2005). To add to this problem, listening in a test situation usually requires precise comprehension and precludes opportunities to clarify or negotiate with the speaker (Buck, 2001). $\mathrm{L}_{2}$ learners often regard listening as the most difficult language skill to learn (Hasan, 2000; Graham, 2003). One of the reasons might be that learners are not taught how to learn listening effectively (Vandergrift, 2007). Another reason might be that the listener can not refer back to the text in contrast to a reader who usually has the opportunity to refer back to clarify understanding (Stahr, 2009). Consequently, listening becomes a cause of anxiety for $\mathrm{L}_{2}$ learners (See Elkhafaifi, 2005; Noro, 2006). Adding to the fact that learners recognize listening as the most difficult skill to learn, it is noticeable that $\mathrm{L}_{2}$ listening remains the least researched of all four language skills (Kurita, 2012; Vandergrift, 2007). Accordingly, to investigating the listening comprehension process can provide useful insights into teaching listening. In addition, to know why students may find the listening comprehension task difficult may also provide us with opportunities to alter our teaching techniques. It is commonly believed that learners who learn to control their listening process can enhance their comprehension (See Guan, 2015; Liu, 2010).

Despite its importance in the development of second language proficiency, there is little research on listening comprehension in a second language (Bloomfield et al., 2010). Unfortunately, most second language comprehension research has focused on reading rather than listening because the process of reading is more easily observed and manipulated (Osada, 2004). Moreover, research findings from reading comprehension research often fail to map fully onto the process involved in listening comprehension (Schmidt-Rinehart, 1994). In addition, as Shohamy \& 
Inbar (1991), Crystal (2003) and Ito (2001) point out, many factors relevant for listening comprehension have no analogue in reading comprehension. Speech may contain irregular pauses, false starts and intonation patterns that can affect comprehension. The pronunciation of words may also differ greatly from the way they appear in print and may be affected by the words with which they are presented. Developing listening comprehension ability would enable the learners to succeed in $\mathrm{L}_{2}$ acquisition in terms of increasing comprehensible input (See Hamouda, 2013; Osada, 2004).

\section{Literature Review}

\subsection{Listening Comprehension and $L_{2}$ Teaching Theory/Learning}

Modern-day concern of listening comprehension in language studies appeared first in the mid-1960s (Morley, 1990). Around the time of $1970 \mathrm{~s}$ and 1980s, listening comprehension became significant in language learning. Some teaching methods, "Total Physical Response" and "Natural Approach" put more emphasis on students" comprehension process in one-way or two-way communication (See Chih-Yu, 2005). As Moody (1984) points out, research has demonstrated that adults spend $40-50 \%$ of communication time listening; however, the importance of listening in language learning has only been recognized relatively recently (Oxford, 1993). As Feyten (1991) explains, listening has emerged as an important component in the process of $\mathrm{L}_{2}$ acquisition. Krashen's emphasis on the role of comprehensible input was partly responsible for the importance given to listening comprehension. The importance of comprehensible input as a necessary factor in $\mathrm{L}_{2}$ learning is documented in the SLA literature. Krashen (1982) urged that the most effective way to teach a second language is to give learners large amounts of comprehensible input in an environment of low anxiety.

Second language acquisition researchers seem to agree that as input is converted into intake, learners make use of listening for two purposes; comprehension and acquisition. It must be worth-mentioning, however, that not all input becomes intake; that is, not everything that is understood at the message level necessarily contributes to the learners' language development. Although it is plausible that comprehension is prerequisite to acquisition, research has shown that we do not learn anything from the input we hear and understand unless we notice something about it (Schmidt, 1990). In addition, Schmidt and Frota (1986) found that there was a close connection between noticing features of the input, and their later emergence in speech. Listening is an important language skill to develop in terms of $\mathrm{L}_{2}$ acquisition (Kurita; 2012; Vandergrift, 2007). As Swain (1995) points out, second language acquisition studies have demonstrated that comprehensible input is critical for language acquisition as well as comprehensible output: "a key difference between more successful and less successful acquires relates in large part to their ability to use listening as a means of acquisition" (Rost, 2001: 94). Accordingly, acquiring good listening skills in second language has been one of the main concerns of language teaching (See Kemp, 2010; Sadighi \& Sare, 2006; Jafari \& Hashim, 2015).

The concept of "comprehensible input" brings to the surface an important issue that has to do with defining listening as a "highly complex problem solving activity" (Byrnes, 1984:9). In this regard, it has been hypothesized that background knowledge and schemata plays a significant role in the comprehension of this highly complex problem-solving activity. During listening, the listeners are engaged in the process of constructing meaning from the text they listened to base on their expectations, inferences, intentions, prior knowledge. That is, listeners combine their previous experiences and pre-existing knowledge with the text they hear. This means that listening comprehension is the results of the interaction between 'bottom-up' and "top-down" processing. Listeners process a listening text through bottom-up process in which they decide what they hear; that is, they construct a message from sounds, words, and phrases. In addition to their linguistic knowledge, listeners also make inferences about what the speaker intended through top-down processing (See Zeng, 2007; Zhang, 2006; Goh, 2006; Graham, 2006; Mohseny \& Raeisi, 2009).

Not only is listening comprehension important at the beginning stages of SLA, it appears to be crucially important for advanced-level learners (Power, 1985). Peterson (1991:106-107) maintains that no other type of language input is as easy to process as spoken language received through listening. At the beginning stages of language study, before students have learned to read well, it is by listening that they can have the most direct connection to the meaning of the new language. They can use spoken language to build an awareness of the inter-workings of language systems at various levels and thus establish a base for productive skills. At the intermediate level, when students are refining the grammatical system of the language, listening can be used to promote accuracy. At advanced levels, when written language becomes a viable source of input, a regular program of listening can extend the limits of learners' vocabulary and use of idioms, and build their appreciation for cultural nuances. Now, many contemporary foreign language educators and researchers regard comprehensible input (written as well as spoken) as essential to developing the ability to produce the target language fluently. Accordingly, listening comprehension has become the foundation of a number 
of theories of second language acquisition that focus on the beginning levels of second language proficiency. The primary assumption underlying these theories is that language acquisition is an implicit process in which linguistic rules are internalized by extensive exposure to authentic texts and particularly to comprehensible input that provides an appropriate level of challenge to the listener (See Nadig, 2013; Pourhosein \& Ahmadi, 2011 a,b).

Listening is used for more than any other single language skill in normal daily life. On average, we can expect to listen twice as much as we speak, four times more than we read, and five times more than we write (River, 1981). Relatedly, Morley (1991:82) maintains that the importance of listening cannot be underestimated; it is imperative that it not be treated trivially in second and foreign language curricula. Rankin (1962:2) points out that of the time adults spend in communication activities 45 percent is devoted to listening, only 30 percent to speaking, 16 percent to reading, and a mere 9 percent to writing. Accordingly, Morley (1991) maintains that we need to realize that listening is anything but a passive activity. In addition, Dunkel (1991:438) maintains that listening research should be fostered to advance the state of SLA theory building, and to expand the knowledge base about the process of $\mathrm{L}_{2}$ comprehension and the effective methods of teaching $\mathrm{L}_{2}$ listening comprehension (See Rost, 2002; Nadig, 2013; Gilakjani \& Sabouri, 2016).

\subsection{The Nature of the Listening Comprehension}

Listening, as described by Wipf (1984), is an invisible mental process, making it difficult to describe. In its broadest sense, listening is a process of receiving what the speaker actually says (receptive orientation); constructing and representing meaning (constructive orientation), negotiating meaning with the speaker and responding (Collaborate orientation); and, creating meaning through involvement, imagination and empathy (transformative orientation). In this sense, listening is a complex, active process of interpretation in which listeners match what they hear with what they already know (Vandergrift, 2008; Vandergrift \& Tafughodtari, 2010). Recently, listening has been described as an interactive and interpretive process where listeners use both linguistic knowledge and prior knowledge in understanding messages. As Vandergrift (2008) points out, the degree to which listeners use the one process or the other depends on their knowledge of the language, familiarity with the topic or the purpose for listening. Research from cognitive psychology has shown that listening comprehension is more than extracting meaning from incoming speech. As Byrners (1984) points out, it is a process of matching speech with what listeners already know about the topic and, therefore, when listeners know the context of a text or an utterance, the process is facilitated considerably because listeners can activate prior knowledge and make the appropriate inferences essential to comprehending the message. O'Malley \& Chamot (1990:133) provided a practical definition of listening comprehension. "Listening comprehension is an active and conscious process in which the listener constructs meaning by using cues from contextual information and from existing knowledge, while relying upon multiple strategic resources to fulfill the task requirements" (See Chang, 2008; King, 2006; Yesilyurt, 2013).

According to Rubin (1994:199), there are, at least five factors that researchers believe affect listening comprehension:1) text characteristics (variation in a listening passage/text or associated visual support); 2) interlocutor characteristics (variation in the speaker's personal characteristics); 3) task characteristic (variation in the purpose for listening and associated responses); 4) listener characteristics (variation in the listener's personal characteristics) and 5) process characteristics (variation in the listener's cognitive activities and in the nature of the interaction between speaker and listener). There remains a great deal that is not known about what makes listening materials difficult for $\mathrm{L}_{2}$ learners. For more on this point, See Gilakjani \& Ahmadi, 2011; Steinberg, 2007; Azmi et al., 2014).

One of the factors that may determine the difficulty of the listening passage is passage length; that is the amount of information presented in the passage is often a factor of concern (See Alderson et al., 2006; Rost, 2006). First, $\mathrm{L}_{2}$ listeners often fixate on information they have failed to comprehend, investing additional effort in trying to understand what they missed (Goh, 2000). Second, if listeners avoid fixating, they may be unable to comprehend later information (see Carell et al., 2002; Kostin, 2004; Moyer, 2006). As Bloomfield et al. (2010) argue, greater amounts of information may put a strain working memory, especially that working memory plays a critical role in listening. In summary, the preceding discussion shows that there are numerous difficulties to be encountered in listening comprehension, such as unknown vocabulary, unfamiliar topics, fast speech rates, and unfamiliar accents (for fuller discussion on these factors (see Buck 2001; Chang \& Read, 2008; Azmi et al., 2014; Graham, 2006; Chen, 2010; Walker, 2014).

\subsection{Listening Comprehension and Linguistic Research}

Linguistic research has investigated knowledge that contributes to listening comprehension. The focus, first, has been on how much lexical knowledge contributes to comprehension. As reported in Kurita (2012:35), Stahr (2009) found that vocabulary size and depth of vocabulary knowledge are both significantly correlated with listening 
comprehension and asserts that vocabulary size is the basic component of vocabulary knowledge in listening comprehension and that depth of vocabulary knowledge does not play a separate role. In addition, linguistic investigation of the listening comprehension skill has, also, focused on the role of acoustic input such as phonological modification and prosody in improving $\mathrm{L}_{2}$ learners' word perception. Field (2008), for example, examined how the phonology of $\mathrm{L}_{1}$ constraints the perception of $\mathrm{L}_{2}$ at the phonemes level. Also, Altenberg (2005) found that $\mathrm{L}_{2}$ learners are significantly worse than native speakers at using acoustic phonetic cues, and that some types of stimuli are easier for learners to identify than others.

Although there is a range of research arguing that there may be a strong relation between grammar and reading (Grabe, 2004), the importance of grammar knowledge for listening has been less explored. It must be emphasized, here, that; the knowledge of the structure of English allows us to grasp the meaning of sentence in the comprehension process" (Anderson, 2009:242). However, Mecartty (2000) states that grammatical knowledge does not contribute significantly to either listening or reading comprehension, but vocabulary knowledge plays the important role in $\mathrm{L}_{2}$ listening comprehension ability. This may be due to the fact that some learners, particularly early stage learners, have difficulty in attending to both form and content in listening. In conclusion, recent linguistic research makes it clear that 'vocabulary knowledge is an important predictor for listening comprehension and, listeners are likely to pay attention to content words, stress and intention rather than function words and grammar in bottom-up processing' (Kurita, 2012:36; Teng, 1997; 2003).

\subsection{Listening Comprehension and Cognitive Research}

In cognitive psychology, Anderson (2009) breaks down the language comprehension process into three stages. The first stage (perception) involves the perceptual process that encodes the spoken message. In the second stage (parsing), the words in the message are transformed into a mental representation of the combined meanings of the words. In the third stage (utilization), listeners use the mental representation of the sentences' meaning. These three stages are, by necessity, partly ordered in time and, partly, overlap; that is, listeners can make inferences from the first part of a sentence while they perceive a latter part.

There are three types of strategies in listening comprehension: (1) cognitive strategies; (2) metacognitive strategies and (3) socio-affective strategies. First, cognitive strategy is a problem-solving method that learners apply to deal with the learning activity and facilitate the learning of knowledge (Azmi et al, 2014). As Gilakjani \& Sabouri (2016) explain, cognitive strategies are related to understanding and gathering input in short term memory or long-term memory for later use. There are two kinds of cognitive strategies: (1) bottom-up strategies are word-for-word translation, arranging the rate of speech, repeating the oral text, and concentrating on prosodic characteristics of the text, (2) top-down strategies involve forecasting, guessing, explaining and visualization. This type of strategies is mostly used by advanced learners (See Abdalhamid, 2012).

Second, metacognitive strategies are management techniques used by learners to control their learning through planning, checking, assessing and changing (See Rubin, 1988). Kurita (2012) maintained that the research focusing on the differences between more-skilled and less skilled $\mathrm{L}_{2}$ learners has provided ample evidence of the importance of the metacognitive strategies to $\mathrm{L}_{2}$ listening success. Research has shown that skilled listeners reported using about twice as many metacognitive strategies as their less-skilled counterparts (See Vandergrift, 2003, 2007; Goh, 2008; Field, 1998; Chang \& Read, 2008; Lee, 1997; Chang, 2003; Yong, 2009; Al-Awan et al., 2013).

Third, socio-affective strategies are techniques that listeners use to cooperate with others, to check their comprehension, and to reduce their apprehension (Gilakjani \& Sabouri, 2016; Vandergrift, 2004; Hebta-Gabr, 2006). In addition, many researchers have revealed that affective variables play a large role in the learners' performance. Elkhafaifi (2005) found that foreign language learning anxiety and listening anxiety are separate but both correlated negatively with achievement. That is, the listening process in easily disrupted by anxiety and separately, listening tasks themselves may cause listening anxiety. Chang (2008) and Chang \& Read (2008) reported that their participants gave four main reasons for their anxiety before they took the listening tests, firstly, most people reported listening only once, secondly, concern about the mark they would obtain, third, worrying that the test would be very difficult, and, fourth, lack of confidence. Moreover, researchers paid a great amount of attention to motivation as an important affective variable. As Vandergrift (2007:196) points out "motivation and metacognition appear to be elements that are part of clusters of variables contributing to variance in $\mathrm{L}_{2}$ listening" (See Kemp, 2010, for more discussion on motivation and its role in $\mathrm{L}_{2}$ listening comprehension).

Vandergrift (1999) points out that metacognitive strategies lead to listening achievement when they deal with cognitive strategies. Less efficient learners utilize cognitive and memory strategies most frequently and social strategies least frequently. Research studies by Graham et al. (2008), and Shang (2008) showed that the more 
efficient learners often applied strategies. They used top-down and metacognitive strategies which are related to the learners' listening skill. The less efficient learners utilize bottom-up strategies. For more studies on listening strategies, see Chulim, 2008; Vandergrift, 1997; Vandergrift et al., 2006; Al-Alwan et al, 2013; Yang, 2009; Coskun, 2010; Bozorgian, 2012; Bidabadi \& Yamat, 2011; Tavakoli et al., 2012; Rahimi \& Katal, 2012. In general, these studies showed the following: (1) the most frequent use of strategies was emphasizing on particular information, while taking notes and previous knowledge were the least strategies (Chulim, 2008); (2) students at different course levels used metacognitive, cognitive and socio-affective strategies. Cognitive strategies were the largest percentage of strategies followed by metacognitive strategies which increased by proficiency level (Vandergrift, 1997). This finding indicates that students with high levels of metacognitive consciousness are better at processing and keeping new information. This means that metacognitive strategies can activate thinking and guide and improve learners' learning performance (Anderson, 2003; Al-Alwan et al., 2013); (3) metacognitive strategies have significant role in helping learners to undertake the listening activity more effectively (Goh, 2006). This finding may imply that metacognitive strategy training can be used in the listening classes to further the listening process; (4) metacognitive strategies are used to plan and perform suitable actions to get a specific aim. In addition, proficient learners seem to have higher metacognitive, cognitive, and socio-affective awareness (Lui, 2008; Bidabadi \& Yamat, 2011; Tavakoli et al., 2012).

\section{The Present Study}

\subsection{The Purpose}

The major question that this study attempts to answer is "Whether listening comprehension a language problem or listening problem?" This question can be simply expressed in the following sub-questions:

(1) To what extent does the advanced students' performance in listening tasks differ from that of the beginning students?

(2) To what extent does the subjects' performance in listening tasks improve as a result of: (a) intensive reading of the listening material, and

(b) Intensive exposure (through listening) to the listening material;

(3) What are the strategies used by advanced and beginning learners in answering listening questions, and

(4) Does the subjects' performance in listening tasks differ from one task to another?

\subsection{Methods}

\subsubsection{Subjects}

Two groups of subjects participated in the current study $(\mathrm{N}=46)$. The first group (beginners) consisted of twenty-three first year students in the Department of English at the Faculty of Education, Menufia University, Egypt. Their scores in the General Secondary School Certificate ranged from $87 \%$ to $92 \%$. These students represent the "Beginners" group. Twenty three fourth year students in the same department participated in this experiment. They represent the "Advanced" group.

\subsubsection{Instruments}

The instruments of this study consisted of five tasks:

A. Pre-test. This test was made of two parts; the first part consisted of 20 questions of part A from a TOEFL test, listening comprehension section. The second part was made of 15 conversations from part B of the same test. Each correct answer in both parts was worth two points. (See Appendix)

B. Questionnaire. Having accomplished the above task, the subjects were asked to truthfully report on their performance. Specifically, they were asked to pinpoint the problems they faced while working on the pre-test, and the strategies they used to overcome these problems.

C. Classroom instruction session. The subjects were asked to come the next day following the pre-test to attend a group discussion on the test they had taken. Each student had a copy of the sentences and conversations of the pre-test. Together we discussed them and the purpose was to make them familiar with the vocabulary, grammatical structures, and to answer any questions related to the linguistic aspects of these sentences and conversations. I was very careful not to give them any cues to the correct answers. It may be important to mention that the subjects were not exposed to the choices from which they will pick the correct answer. That is, they were only exposed to the sentences and conversation they hear on the tape. In the end of this session, the subjects were asked to come again after two weeks. At that time I did not tell them why they should come. 
My only question was 'Do you still have any problem with these sentences?'; and the response was "No". (See Appendix)

D. Post-Test. The subjects were asked to work on the test used before. To be sure that their responses reflect their real listening, the order of the sentences and conversations was changed. The subjects were asked to listen carefully.

E. Interviews. Each student was interviewed to explain his/her performance in the post-test. I interviewed the students individually. Conducting the interview with each subject took about one hour to one hour and half. During the interview, students were asked to explain why a certain answer was. No feedback on the correctness of their responses was given before the end of the interview. Students' explanations were tape-recorded, and transcribed.

\subsubsection{Data Analysis}

The data analysis had a quantitative and a qualitative, interpretative part. The quantitative part consisted of a descriptive statistical comparison of the number of correct responses in part (A) and part (B) of the listening test, in the pre and post tests. The T-test was applied to determine the significance of differences between means. The qualitative part was an analysis of each student's performance in the pre and post tests. The analysis was inductive, based on the individual's explanations, and aimed at accounting for the differences between the tasks.

\section{Results / Discussion}

\subsection{Summary Statistics}

The statistical analyses (See Appendix) indicate that the condition (part A and part B) affected the number of correct responses made by the subjects. This suggests that the subjects' performance in listening comprehension skill is not a unitary one. That is, it differs from one task to another. For example, in part (A), which is made of short statements, the beginning subjects' total score was 310 out of 920 . The mean number of correct responses in part (A) in the pre-test was 13.48 with a standard deviation of 4.14. In part (B), which is made of short conversations, the subjects' total score was 214 out of 690. The mean number of correct responses in part (B) in the pre-test was 9.30with a standard deviation of 3.62. Similarly, the advanced subjects' total score in part A of the (pre- test was 476 out of 920 . The mean number of correct responses inpart A was 20.70 with a standard deviation of 5.26. In part B of the pre-test, the advanced subjects' total score was 370 out of 690 . The mean number of correct responses in part B in the pre-test was 16.09 with a standard deviation of 4.15 .

The above results may support the variability position (McLaughlin, 1987). Stated simply, the variability position maintains that $\mathrm{L}_{2}$ learners' performance varies according to the kind of language use that they engage in and the kind of knowledge they acquire. As shown before, the subjects of this study varied in terms of the number of correct responses in both listening tasks, and in the pre-and post-tests. This suggests that $\mathrm{L}_{2}$ learners' proficiency is not an absolute construct; rather, it relies on what kind of language task the learner is performing. To put it differently, we will be mistaken to expect the learner who performs highly in one task to, necessarily, perform at the same high level in another task. Instead, we need to keep in mind that students' performance is not systematic, and we should accept the variability in our students' performance. Tarone (1984) found the same evidence in speaking tasks, and that the variability in students' performance is similar to Tarone's notion of a "capability continuum". Specifically, Tarone maintained that one phenomenon which must be accounted for by any theory of second language acquisition is the phenomenon of systematic variability in the utterances produced by second language learners as they attempt to communicate in the target language.

The beginning subjects' performance in the post-test provides more support to the variability position. Comparing their performance, in both parts, in the pre-test to their performance in the post-test shows that listening comprehension is, in part, a language problem. In the pre-test, the subjects did not perform well enough because, in part, their knowledge seemed to be deficient. When they became aware of the linguistic elements of the listening material, their performance significantly improved. For example, in the post-test, the subjects' total score was 696 out of 920 in part (A), and 554 out of 690 in part (B). In other words, the mean number of correct responses in part (A) of the post-test was 30.26 with a standard deviation of 6.11. Moreover, the mean number of correct responses in part (B) of the post-test was 24.09 with a standard deviation of 3.01. In general, the mean number of the subjects' total score in the pre-test (parts A and B) was 22.78 with a standard deviation of 5.13. The mean number of the subjects' total score in the post-test was 54.35 with a standard deviation of 8.54. Similarly, the advanced subjects' performance in the post-test provides an additional support to the variability position. Comparing their performance, in both parts, in the pre-test to their performance in the post-test shows that listening comprehension is a listening problem. It has been previously shown that for beginners 
the listening comprehension skill is, in part, a language problem. For advanced learners, it is, in part, a listening problem. In the pre-test, the advanced subjects did not perform very well. Having intensively listened to the test material, their performance significantly improved. For example, in the post-test, the subjects' total score was 744 out of 920 in part A, and 516 out of 690 in part B. In other words, the mean number of correct responses in part (A) of the post-test was 32.35 with a standard deviation of 5.26. And, the mean number of correct responses in part B of the post-test was 22.44 with a standard deviation of 4.97. In general, the mean number of the advanced subjects' total score in the per-test (parts A and B) was 36.78 with a standard deviation of 8.23. The mean number of the subjects' total score in the past-test was 54.78 with a standard deviation of 9.30 . The above data clearly show that because of the training session, in which the subjects were provided with linguistic knowledge related to the listening material, the subjects' performance in both parts of the test significantly developed.

The qualitative analysis of the data showed that there are many reasons for students' unsuccessful responses, in addition to students' incomplete linguistic knowledge. Two of the major reasons are (1) the complexity of the listening skill; therefore, students were unable to do more than one thing simultaneously during listening, and (2) students' failure to focus enough to get the meaning and, then, pick up the correct choice. Based on the subjects' explanations during the interview, one can argue that listening to a second language is a multidimensional activity which requires $\mathrm{L}_{2}$ learners to do more than one thing simultaneously. This argument is compatible with the principles of the attention theory (James, 1890). Two important features within the phenomenon of attention have been identified: (1) An individual can attend to only one thing at a time or think only one thought at a time. (2) Attention appears to be serial, in that we appear to attend to or perform first one thing, then another, and we find it very difficult to mix certain activities. That is, the focus of attention is only on one place at one time. In this regard, James (1890:403-404) suggests that "[attention] is the taking possession by the mind, in clear and vivid form, of one out of what seem several simultaneously possible objects or trains of thought. Focalization, concentration, of consciousness are of its essence. It implies withdrawal from some things in order to deal efficiencly with others".

In addition, Broadbent (1971) pointed out that our ability to attend to several sources of information simultaneously is severely restricted. Consequently, a human who must process information that exceeds his channel capacity will inevitably make errors. This means that students' incorrect answers and their success in correcting some of them in the post-test can be explained within the principles of attention theory. That is, some $\mathrm{L}_{2}$ learners may appear to have the necessary knowledge to make correct responses; however, they are unable to display this knowledge while listening to spoken English. This phenomenon was previously analyzed as an indication of the level and depth of students' knowledge. At the same time, we need to be open to other possible explanations. In this regard, I argue that the attention theory, as explained by cognitive psychologists, may provide us with a reasonable and plausible perspective of students' performance. That is, some $\mathrm{L}_{2}$ learners may appear to have the necessary knowledge for successful listening; however, they are unable to display this knowledge during listening. In this regard. Foder, Bever, and Garrett (1974) suggest that native language words are held in short-term memory only long enough for the listener to organize them into clauses and to extract the meaning that they convey. As soon as the listener has interpreted the clause, the elements that made it up are purged from memory in order to make room for incoming sounds. As Call (1985) points out, foreign language input seems to be processed in the same way, but, as Rivers and Temperley (1978) point out, short-term memory for target language words is often overloaded, causing words to be purged before they can be organized and interpreted. Thus, even though language learners may be able to recognize each word of an utterance as it is spoken, they may not be able to hold lengthy utterances in mind long enough to interpret them. The capacity of short term memory is limited to about seven units, plus or minus two (Miller, 1956; Klatzky, 1975).

Student: I try to get the meaning of the sentence when I was listening but sometimes .... I got confused because of the four choices.... They are confusing.

Moreover, the qualitative data support the results of my previous research on $\mathrm{L}_{2}$ learners' listening comprehension skill (El-daly, 2010). More specifically, the subjects' incorrect responses were mainly due to the following reasons: (1) total unsuccessful listening or fragmentary listening; (2) failure to listen, read the four choices and pick up the correct choice in a very short time; (3) failure to catch the meaning of the whole sentence or relate the words together to make clear semantic representations and (4) syntactic deficiency which negatively affects subjects' total understanding of the whole sentence.

Student: If the sentecne or the conversation is so long I only get half of the sentence or some words.

Student: $\quad$ Time is very short .... I listen first .... I have to read the four choices... I can not do all this quickly.

In addition, during the interview the subjects displayed some interesting characteristics that are worth to be considered. First, some of the correct answers of the subjects were based on false rationalizations. This observation suggests that 
assessing second language learners' performance in listening is not an easy task. That is, relying only on the number of correct responses in the listening comprehension of the TOEFL may not be an accurate or valid measure of students' linguistic abilities. The number of correct responses only tells us that subjects were able to pick this number of the correct responses, but it does not tell us anything about how accurate their listening comprehension skill is. That is, making the least number of errors does not necessarily mean that the subjects are linguistically competent, or vice versa. The point, here, is that we need to consider students' performance from more than one perspective. In addition to the number of correct responses, we need to uncover the knowledge-base structure that determines students' correct choices. Relatedly, we need to uncover the strategies that may help students to reach correct responses. These additional measures are suggested here since we sometimes wonder whether the correct responses are due to strong linguistic background, or to adopting successful strategies, or it is just a matter of luck. Based on subjects' explanations of their overall performance in the two listening comprehension tasks, it can be argued that their errors were not just due to carelessness or forgetfulness. Rather, deficiency in their overall linguistic abilities, in general, and in their listening comprehension skill, in particular, is the main reason for their unsuccessful performance. Another possible explanation is that the task demands can be a factor in determining students' success or failure in displaying their knowledge and using it successfully.

The study showed that the subjects relied on many strategies in reaching correct answers: (1) focusing on certain key words; (2) relying on syntactic and semantic representations; (3) getting the overall meaning even when some words are missed (4) reading the four choices in advance, and (5) complete and successful listening comprehension but, unfortunately, in only few cases. Based on the subjects' explanations, it can be argued that advanced language learners resort to various types of strategies. However, their success or failure is constrained by the depth and completeness of their knowledge as well as the nature of the task they are performing. Second language learners' strategies are, in essence, knowledge-driven. Consequently, in thinking about their performance as an object of study, the essence of the underlying knowledge that accounts for their performance must be examined. The examination of the learners' underlying knowledge will, in turn, uncover the basis for the strategies they use in solving language problems. It must be kept in mind that when we talk about knowledge, we do not only talk about the presence versus absence of knowledge, but also the depth, completeness, and accuracy of such knowledge. And, because subjects' knowledge was not as complete as it should be, their strategies were not as successful as we all hope. And, since their knowledge was fragmentary, some subjects failed to provide rational justifications for their correct responses. Rather, they tended to rely on totally unrelated, even, strange reasons.

Student: Sometimes I focus on certain words to make my choice.

Student: I try to read the choices quickly before listening to the sentence ... I try to match words.

\section{Pedagogical Applications}

To understand a piece of spoken discourse one has to have not only knowledge of the language, but also some background knowledge of the world. In his book, "Communicative Language Teaching", Littlewood (1981:26) points out: "Listening demands active involvement from the learner. In order to reconstruct the message that the speaker intends, he must actively contribute knowledge from both linguistic and nonlinguistic sources". The purpose of pre-listening activity is to elicit the learners' background knowledge and prepare them for what is going to be said. Pre-listening activity makes it possible for all students to share common background knowledge before listening. We cannot, for example, expect all students to have the same level of knowledge about a particular world event. Some students who are concerned with or interested in international affairs and read newspapers regularly will know more than those who do not. The pre-listening activity makes it possible for the students to pass on the information they have to others, and thus all students can share common background knowledge before listening. Pre-listening activity can help to elicit from the students their own background knowledge. When all students are aware of the event they are going to listen to, the teacher may put some more questions for them to discuss in pairs or in groups. When all this background knowledge has been elicited, the teacher needs to create an information gap or set a task for them just before they listen to the text.

Another advantage of the pre-listening activity is that it makes it possible to set "new" vocabulary items in the context. In listening to news reports, students will inevitably come across new words or phrases, which often panic them. Presenting new words and phrases before listening did help students to a certain extent. However, since the words were given as separate items, and not in context, students had to make efforts to fit them into the text while listening. A word list given in this way does not seem to help much in listening comprehension. In a pre-listening activity, however, we can put new words and phrases into context. 
It must be made to clear to teachers that listening comprehension does not mean 100 per cent correct understanding. In listening to English news broadcasts, it is the general idea, the subject matter and the meaning, not the individual words and forms that we are going to remember. Various kinds of techniques or exercises can be used to lead the students to focus on the general idea and the subject matter of the news to which they are listening. Concentrating and understanding the topic sentence, which is usually the first sentence of the news, will make the entire listening text predictable. Discovering repeated and stressed words can help the students to extract the relevant information from the spoken discourse. Teachers should ask more global, rather than partial comprehension questions. Specific and detailed questions are asked only after the students have recognized the major idea of the news item.

The most common problem facing the teacher is how to choose and grade the recorded material. An English radio program varies in content and covers a wide range of topics. What kinds of news items are we to choose? According to my experience, the following principles can be used as a guide in choosing teaching material. Every teacher knows that interesting material can activate and simulate students learning, while uninteresting material will make the work boring. This remains true when we use news, programs as teaching material. The teacher should choose those news items that will interest the students. It is true that different students have different interests, and it is, in principle, not possible to find material that will interest everyone. But this does not mean that there are no topics of common interest. Labov found that people were always ready to talk about the "danger of death." Brown (1977) suggests that the perennially interesting conversations presumably are concerned with power, sex, and danger. In different cultures and societies, people may have different interests. But generally speaking, people are most concerned with their own affairs. In news reporting, they are more interested in what is happening in their own country than in other areas. Closely related to interest, news items chosen for teaching listening comprehension should be more or less familiar to the students. Generally speaking, students like to listen to those topics of the news that are familiar to them. Familiar topics may or may not be interesting, but the important factor is that students find them easier to understand. Brown (1977) says that it ought to be easier for a student to understand content that he is more familiar with.

Change in the way we think about learning and what we know about the way learning occurs have important implications for those situations in which we want to facilitate changes in what people know and/or do. In education, for example, corresponding changes are occurring in the way we think about teaching. Since learning is an active process, the teacher's task necessary involves more than the mere dissemination of information. Rather., if students are to learn desired outcomes in a reasonably effective manner, then the teacher's fundamental task is to get students to engage in learning activities that are likely to result in their achieving their outcomes, taking into account factors such as prior knowledge, the context in which the material is presented, and the realization that students' interpretation and understanding of new information depend on the availability of appropriate schemata. Without taking away from the important role played by the teacher, it is helpful to remember that what the student does is actually more important in determining what is learned than what the teacher does.

Finally, it is recommended that listening comprehension assessment focus more on fostering students' listening processes that improve their listening skill rather than merely testing their recall of listening content. In this connection, I do agree with Chen (2013) who points out that there is a pressing need to develop appropriate testing systems that measure the listening performances which students are actually developing.

\section{References}

Abdalhamid, F. (2012). Listenign comprehension strategies of Arabic-speaking ESL learners. Master's Dissertation, Department of English, Colorado State University, Fort Collins, Colorado.

Al-Awan, A., Asassfeh, S. \& Al-Shboul, Y. (2013). EFL learners' listening comprehension and awareness of metacognitive strategies: How are they related? International Education Studies, 6(9), 31-39.

Alderson, J., Figueras, N., Kuijper, H., Nold, G., Takala, A. \& Tardieu, C. (2006). Analyzing tests of reading and listening in relation to the common European framework of reference: The experience of the Dutch CEFR Construct Project. Language Assessment Quarterly, 3(1), 3- 30. http://dx.doi.org/10.1207/s15434311laq0301_2

Altenberg, E. (2005). The perception of word boundaries in second language. Second Language Research, 21, 325-358. http://dx.doi.org/10.1191/0267658305sr250oa

Anderson, J. (2009). Cognitive psychology and its implications. Seventh Edition, NY: Worth Publishers.

Azmi, B.M., Celik, B., Yildiz, N. \& Tugrul, M.C. (2014). Listening comprehension difficulties encountered by students in second language learning class. Journal of Educational and Instructional Studies in the World, 4(4), $1-6$. 
Baddeley, A. (2007). Working Memory, Thought and Action. Oxford: Oxford University Press. http://dx.doi.org/10.1093/acprof:oso/9780198528012.001.0001

Bejar, I., Douglas, D., Jamieson, J., Nissan, S. \& Turner, J. (2000). TOEFL 200 listening framework: A working Paper, Princeton, NJ: Educational Testing Service.

Bidabadi, F. \& Yamat, H. (2011). The relationship between listening strategies used by Iranian EFL freshman university students and their listening proficiency levels. English Language Teaching, 4(1), 26-32. http://dx.doi.org/10.5539/elt.v4n1p26

Bloomfield, A., Wayland, S., Blodgett, A. \& Luck, J. (2010). Factors related to passage length: Implications for second language listening comprehension. University of Maryland, College Park 2317-2322.

Bozorgian, H. (2012). Metacognitive instruction does improve listening comprehension. International Scholarly Research Network, 1-6. http://dx.doi.org/10.5402/2012/734085

Broadbent, D. (1971). Decision and Stress. London: Academic Press.

Buck, G. (2001). Assessing listening. Cambridge: Cambridge University Press. http://dx.doi.org/10.1017/CBO9780511732959

Byrnes, H. (1984). The role of listening comprehension: A theoretical base. Foreign Language Annals, 17, 318-330. http://dx.doi.org/10.1111/j.1944-9720.1984.tb03235.x

Call, M. (1985). Auditory Short-term Memory, Listening Comprehension, and the Input Hypothesis. TESOL Quarterly, 19(4), 765-781. http://dx.doi.org/10.2307/3586675

Carrell, P., Dunkel, P. \& Mollaun, P. (2002). The effects of note taking, lecture length and topic on the listening component of the TOEFL 2000. Princeton, NJ: Educational Testing Service.

Chang, A.C.S. \& Read, J. (2008). Reducing listening test anxiety through various forms of listening support. TESL-EJ, 12, 18-29.

Chang, A.C.S. (2008). Listening strategies of $\mathrm{L}_{2}$ learners with varied test tasks. TESL Canada Journal, 25(2), 1-26. http://dx.doi.org/10.18806/tesl.v26i1.127

Chang, H.F. (2003). Listening strategy use of high- and low-level technology college students. Selected Papers from the $12^{\text {th }}$ International Symposium on English Teaching, 164-172.

Chaudron, C. (1985). Intake: On models and methods for discovering learners' processing of input. Studies in Second Language Acquisition, 7, 1-14. http://dx.doi.org/10.1017/S027226310000512X

Chen, A. (2010). Effects of listening strategy training for EFL adult listeners. The Journal of Asia TEFL, 7(1), 135-169.

Chih-Yu, C. (2005). A study of metacognitive strategies in EFL listening comprehension. PhD Thesis, Institute of Applied Foreign Language, Taiwan..

Chulim, F. (2008). The use of listenign learning strategies by Lengua Inglesastudents in five Mexican Universities: Preliminary results. Memorias dellV Foro Nacional de Estudios en Lenguas, 469-479.

Coskun, A. (2010). The effect of metacognitive strategy training on the listening performance of beginner students. Novitas-ROYAL (Research on Youth and Language), 4(1), 35-50.

Crystal, D. (2003). A dictionary of linguistics and phonetics ( $5^{\text {th }}$ edn.). Maladen, MA: Wiley-Blackwell.

Dunkel, P. (1991). Listening in the native and second foreign language: Toward an integration of research and practice. TESOL Quarterly, 25, 451-457. http://dx.doi.org/10.2307/3586979

El-Dali, H. (2010). On the concept of consciousness in $\mathrm{L}_{2}$ acquisition research: Focus on transfer of training in listening comprehension skill. Journal of Education and Sociology, 6, 11-36.

Elkhafaifi, H. (2005). Listening comprehension and anxiety in the Arabic language classroom. The Modern Language Journal, 89, 206-220. http://dx.doi.org/10.1111/j.1540-4781.2005.00275.x

Feyten, C. (1991). The Power of Listening Ability: An Overlooked Dimension in Language Acquisition. The Modern Language Journal, 75, 173-180. http://dx.doi.org/10.1111/j.1540-4781.1991.tb05348.x

Field, J. (2008). Bricks or mortar: Which parts of the input does a second language listener rely on? TESOL Quarterly, 42, 411-432. http://dx.doi.org/10.1002/j.1545-7249.2008.tb00139.x

Fodor, J., Bever, T. \& Garret, M. (1974). The psychology of language. New York: McGraw-Hill Book Company. 
Gilakjani, A. \& Sabouri, N. (2016). Learners' listening comprehension difficulties in English language learning: A Literature Review. English Language Teaching, 9(6), 123-133. http://dx.doi.org/10.5539/elt.v9n6p123

Goh, C. (2000). A cognitive perspective on language learners' listening comprehension problems. System, 28(1), 55-75. http://dx.doi.org/10.1016/S0346-251X(99)00060-3

Goh, C. (2006). Metacognitive instruction in listening for young learners. ELT Journal, 60, 222-232. http://dx.doi.org/10.1093/elt/cc1002

Goh, C. (2008). Metacognitive instruction for second language listening development: Theory, practice and research implications. RELC Journal, 39, 188-213. http://dx.doi.org/10.1177/0033688208092184

Grabe, W. (2004). Research on teaching reading. Annual Review of Applied Linguistics, 44-69. http://dx.doi.org/10.1017/s0267190504000030

Graham, S. (2003). Learner strategies and advanced level listening comprehension. Language Learning Journal, 28, 64-69. http://dx.doi.org/10.1080/09571730385200221

Graham, S. (2006). Listening comprehension: The learners' perspective. System, 34, 165-182. http://dx.doi.org/10.1016/j.system.2005.11.001

Graham, S., Santos, D. \& Vanderpalnk, R. (2008). Listenign comprehension and strategy use: A longitudinal Exploration System, 36, 52-68.

Guan, Y. (2015). A literature review: Current issues in listening strategy research and instruction on ESL adult learners. International Journal of Teaching, Education and Language Learning (IJTELL), 2(1), 32-70.

Habte-Gabr, E. (2006). The importance of socio-affective strategies in using EFL for teaching mainstream subjects. Journal of Humanizing Language Teaching, 8(5), 21-39.

Hamouda, A. (2013). An investigation of listening comprehension problems encountered by Saudi students in the EL listenign classroom. International Journal of Academic Research in Progressive Education and Development, 2(2), 113-151.

Hasan, A. (2000). Learners' perceptions of listening comprehension problems. Language, Culture and Curriculum, 13, 137-153. http://dx.doi.org/10.1080/07908310008666595

Hatch, E., Shirai, Y. \& Fantuzzi, C. (1990). The need for an integrated theory: connecting modules. TESOL Quarterly, 24(4), 697-716. http://dx.doi.org/10.2307/3587116

Holden, W.R. (2004). Facilitating listening comprehension: Acquiring successful strategies. Bulletin of Hokiruku University, 28, 257-266.

Huang, J. (2005). Challenges of academic listening in English: Reports by Chinese Students. College Student Journal, 39, 553-569.

Ito, Y. (2001). Effect of reduced forms on ESL learners' input Intake process. Second language studies, 20(1), 99-124.

Jafari, K. \& Hashim, F. (2015). Comparison of normal and moderately slow speech rates: Listening to students' voices in listening comprehension classes in EFL context. Internatioal Journal of Foreign Language Teaching in in the Islamic World, 3(3), 5-11.

James, w. (1890). The Principles of Psychology. New York: Holt. http://dx.doi.org/10.1037/11059-000

Kemp, J. (2010). The listening log: Motivating autonomous learning. ELT Journal, 64/4, 385-395. http://dx.doi.org/10.1093/elt/ccp099

Kim, S. (2006). Academic oral communication needs of East Asian international graduate students in non-science and non-engineering fields. English for Specific Purposes, 25, 479-489. http://dx.doi.org/10.1016/j.esp.2005.10.001

Klatzky, R. (1975). Human Memory: Structures and Processes. San Francisco, W. Freeman and Company.

Kostin, J. (2004). Exploring item characteristics that are related to the difficulty of TOEFL dialogue items. Princeton, NJ Educational Testing Service. http://dx.doi.org/10.1002/j.2333-8504.2004.tb01938.x

Krashen, S. (1982). Principles and Practice in Second Language Acquisition. Oxford: Pergamon Press. 
Kurita, T. (2012). Issues in social language listening comprehension and the pedagogical implications. Accents Asia, $5(1), 30-44$.

Lee, H.M. (1997). A study of the listening comprehension strategies of junior college EFL students in Taiwan. In Proceedings of 1997 International Conference on English Teaching and Learning in the Republic of China, 393-412.

Littlewood, W. (1981). Communicative Language Teaching. Cambridge University Press.

Liu, J. (2010). Language learning strategies and its training model. International Education Studies, 3(3), 100-104. http://dx.doi.org/10.5539/ies.v3n3p100

Long, D. (1989). Second language listening comprehension: A schema theoretic perspective. Modern Language Journal, 75, 196-204. http://dx.doi.org/10.1111/j.1540-4781.1989.tb05307.x

Long, M. (1985). Input and second language acquisition theory. In S. Gass \& C. Madden (Eds.), Input in Second Language Acquisition, Rowley, MA: Newbury House.

Lui, H.J. (2008). A study of interrelationship between listening strategy use, listenign proficiency levels, and listening style. ARECLS, 5, 84-204.

McCartty, F. (2000). Lexical and grammatical knowledge in reading and listening comprehension by foreign language learners of Spanish. Applied Language Learning II, 323-348.

McLaughlin, B. (1987). Theories of second language learning. London: Arnold.

McLaughlin, B., Rossman, T. \& Mcleod, B. (1993). Second language learning: An information processing perspective. Language Learning, 33, 135-158. http://dx.doi.org/10.1111/j.1467-1770.1983.tb00532.x

Miller, G. (1956). The magical number seven plus or minus two: Some limits on our capacity for processing information. Psychology Review, 63, 81-96. http://dx.doi.org/10.1037/h0043158

Mohseny, A. \& Raeisi, N. (2009). The relationship between language proficiency of EFL students and their strategy use in listening comprehension. TEFLL, 1(4), 111-132.

Morley, J. (1990). Trends and developments in listening comprehension: theory and practice. Georgetown University round table on language and linguistics, 317-337.

Morley, J. (1991). Listening comprehension in second foreign language instruction. In M. Celce-Mmurcia (Ed.), Teaching English as a second or foreign language. New York: Newbury House.

Moyer, A. (2006). Language contact and confidence in second language listening comprehension: A pilot study of advanced learners of German. Foreign Language Annals, 39(2), 255-275. http://dx.doi.org/10.1111/j.1944-9720.2006.tb02265.x

Nadig, A. (2013). Listening Comprehension. Encyclopedia of Autism Spectrum Disorders, 1734.

Nation, S. (2006). How large a vocabulary is needed for reading and listening? The Canadian Modern Language Review, 63, 59-82. http://dx.doi.org/10.3138/cmlr.63.1.59

Noro, T. (2006). Developing a construct model of "listening stress": A qualitative study of the affective domain of the listening process. Annual Review of English Language Education in Japan, 17, 61-70.

Osada, N. (2004). Listening comprehension research: A brief review of the past thirty years. Dialogue, 3, 53-66.

Oxford, R. (1993). Research update on L L listening. System, 21, 205-211. http://dx.doi.org/10.1016/0346-251X(93)90042-F

Payne, J. \& Whitney, P. (2002). Developing $\mathrm{L}_{2}$ oral proficiency through synchronous CMC: Output, working memory, and interlanguage development. Calico Journal, 20(1), 7-32.

Peterson, P. (1991). A synthesis of methods for interactive listening. In M Celce-Murcia (Ed.) Teaching English as a second or foreign language, New York: Newbury House.

Pourhosein, G.A. \& Ahmadi, M.R. (2011a). A study of factors affecting EFL learners' English listening comprehension and the strategies for improvement. Journal of Language Teaching and Research, 2(5), 977-988.

Pourhosein, G.A. \& Ahmadi, M.R. (2011b). The effect of text familiarity on Iranian EFL learners listening comprehension. Journal of Language Teaching and Research, 2(4), 783-789. 
Power, D. (1985). A survey of academic demands related to listening skills. Princeton, NJ: Educational Testing Service.

Rahimi, M. \& Katal, M. (2012). The role of metacognitive listening strategies awareness and podcast-use readiness in using prodcasting for learning English as foreign language. Procedia Social and Behavioural Sciences, 31, 73-81. http://dx.doi.org/10.1016/j.sbspro.2011.12.019

Richards, J. (2005). Second thoughts on teaching listening. RELC Journal, 36, 85-92. http://dx.doi.org/10.1177/0033688205053484

Rivers, W. (1972). Linguistic and psychological factors in speech perception and their implications for teaching materials. In Pirnscur, R. and Quinn, T. (eds.); the psychology of second language learning. Cambridge: Cambridge University Press.

Rivers, W. (1981). Teaching Foreign Language skills. Chicago: University of Chicago Press.

Rost, M. (2002). Teaching and researching listening. London: Longman.

Rost, M. (2006). Areas of research that influence $\mathrm{L}_{2}$ listening instruction. In E. Uso-Juan \& A. Martinez-Floc (Eds.), Current Trends in the Development and Teaching of the Four Language Skills (pp. 47-74). New York: Mouton de Gruyter. http://dx.doi.org/10.1515/9783110197778.2.47

Rubin, J. (1994). A review of second language listening comprehension research. The Modern Language Journal, 78, 199-221. http://dx.doi.org/10.1111/j.1540-4781.1994.tb02034.x

Sadighi, F. Sare, Z. (2006). Is Listening comprehension influenced by the background knowledge of the Learners? A case study of Iranian EFL learners. Linguistics Journal, 1(3), 12-28.

Schmidt, R. \& Frota, S. (1986). Developing basic conversational ability in a second language: A case study of an adult learner of Portuguese. In R. Day (Ed), Talking to learn: Conversational in second language acquisition. Rowley, MA: Newbury House.

Schmidt, R. (1990). The role of consciousness in second language learning. Applied Linguistics II, 129-159. http://dx.doi.org/10.1093/applin/11.2.129

Schmidt-Rinehart, B. (1994). The effects of topic familiarity on second language listening comprehension. Modern Language, 78(2), 179-189. http://dx.doi.org/10.1111/j.1540-4781.1994.tb02030.x

Shohamy, E. \& Inbar, O. (1991). Validation of listening comprehension tests: The effect of text and question type. Language Testing, 8(1), 23-40. http://dx.doi.org/10.1177/026553229100800103

Stahr, L. (2009). Vocabulary knowledge and advanced listening comprehension in English as a foreign language. Studies in Second Language Acquisition, 31, 577-607. http://dx.doi.org/10.1017/S0272263109990039

Steinberg, S. (2007). An introduction to communication studies. Juta and Company Limited.

Sun, Y. (2008). Input processing in second language acquisition: A discussion of four input processing models. Teachers College, Columbia University, Working Papers in TESOL \& Applied Linguistics, 8(1), 1-10.

Swain, M. (1995). Three functions of output in second language learning. In G. Cook \& B. Seidlhofer (Eds.), Principle and practice in applied linguistics (pp. 125-144). Oxford: Oxford University Press.

Tavakoli, M., Shahraki, S. \& Rezazadeh, M. (2012). The relationship between metacognitive awareness and EFL listening performance: Focusing on IELTS higher and lower scores. The Journal of Language Teaching and Learning, 2, 24-37.

Teng, H. (1997). An investigation of EFL listening strategies by Taiwanese college students. The Proceedings of the $6^{\text {th }}$ International Symposium on English Teaching, 508-520.

Teng, H. (2003). Teaching EFL listening strategies to college students in Taiwan. Proceedings of the $20^{\text {th }}$ International Conference on English Teaching and Learning in the R.O.C., 385-394.

Thompson, I. \& Rubin, J. (1996). Can strategy instruction improve listening comprehension? Foreign Language Annals, 29, 331-342. http://dx.doi.org/10.1111/j.1944-9720.1996.tb01246.x

Tyler, M. (2001). Resource conception as a function of topic knowledge in nonnative and native comprehension. Language Learning, 51(2), 257-280. http://dx.doi.org/10.1111/1467-9922.00155

Vandergrift, L. \& Tafaghodtari, M. H. (2010). Teaching $\mathrm{L}_{2}$ learners how to listen does make a difference: An empirical study. Language Learning, 60, 470-497. http://dx.doi.org/10.1111/j.1467-9922.2009.00559.x 
Vandergrift, L. (1997). The comprehension strategies of second language (French) listeners: A descriptive study. Foreign Language Annuals ,30(3), 387-409. http://dx.doi.org/10.1111/j.1944-9720.1997.tb02362.x

Vandergrift, L. (1999). Facilitating second language listening comprehension: Acquring successful strategies. ELT Journal, 53(3), 168-176. http://dx.doi.org/10.1093/elt/53.3.168

Vandergrift, L. (2003). From prediction through reflection: Guiding students through the process of $\mathrm{L}_{2}$ listening. The Canadian Modern Language Review, 59(3), 425-440. http://dx.doi.org/10.3138/cmlr.59.3.425

Vandergrift, L. (2004). Listenign to learn or learning to listen? In Cambridge University Press (Ed.). Annual Review of Applied Lingusitcs, 3-25. Cambridge University Press, USA.

Vandergrift, L. (2007). Recent development in second language listening comprehension research. In Graeme Porte (Ed.). Language Teachign Surveys and Studies, 210-291. Cambridge University Press, Canada. http://dx.doi.org/10.1017/s0261444807004338

Vandergrift, L. (2007). Recent developments in second and foreign language listening comprehension research. Language Teaching, 40, 191-210. http://dx.doi.org/10.1017/S0261444807004338

Vandergrift, L. (2008). Listening comprehension for second language learners. Language Teaching, 42, 26-39.

Vandergrift, L., Goh, C., Mareschal, C. \& Tafaghodtari, M. (2006). The metacognivie awareness listening questionnaire (MALQ): Development and validation. Language Listening, 56, 431-462.

VanPatten, B. (1994). Input processing and grammar instruction on second language acquisition. Norwood, NJ: Albex.

Walker, N. (2014). Listenign: The most difficult skill to teach. Encuentro, 23, 167-175.

Weaver, C. (1972). Human Listening: Process and Behavior. New York: Bobbs-Merrill.

Wipf, J. (1984). Strategies for Teaching Second Language Listening Comprehension. Foreign Language Annals, 7 , 345-48. http://dx.doi.org/10.1111/j.1944-9720.1984.tb03240.x

Wong, J. \& Waring, H.Z. (2010). Conversation Analysis and Second Language Pedagogy. NY: Taylor \& Francis.

Yesilyurt, E. (2013). An analysis of teacher candidates' usage level of metacognitive learning strategies. Language Teaching, 40, 211-229.

Ynag, N. (2009). A study of metacognitive strategies employed by English listeners. International Education Studies, 2(4), 134-139.

Yong, C. (2009). A study of metacognitive strategies employed by English listeners in an EFL setting. International Education Studies, 2(4), 134-139. http://dx.doi.org/10.5539/ies.v2n4p134

Zeng, Ya-Jun. (2007). Schema theory and its application in teaching listening from English major undergraduates. Sino-US English Teaching, 4(6), 32-36.

Zhang. (2006). Effect of Schema Theory and Listening Activities on Listening Comprehension. Sino-US English Teaching, 3(12), 28-31. 


\section{$\underline{\text { Appendix (1) }}$}

Table 1. Achievement of the beginning subjects in the pre- and post-test of the listening comprehension.

\begin{tabular}{lllllll}
\hline & Pre-Test & & & Post-Test & \\
\cline { 2 - 7 } & Part A & Part B & Total & Part A & Part B & Total \\
& $\mathbf{( 4 0 )}$ & $\mathbf{( 3 0 )}$ & $\mathbf{( 7 0 )}$ & $\mathbf{( 4 0 )}$ & $\mathbf{( 3 0 )}$ & $\mathbf{( 7 0 )}$ \\
\hline 1 & 20 & 10 & 30 & 38 & 28 & 66 \\
2 & 8 & 10 & 18 & 36 & 28 & 64 \\
3 & 22 & 8 & 30 & 36 & 28 & 64 \\
4 & 14 & 18 & 32 & 36 & 28 & 64 \\
5 & 14 & 6 & 20 & 36 & 28 & 64 \\
6 & 14 & 8 & 22 & 36 & 28 & 64 \\
7 & 16 & 4 & 20 & 36 & 26 & 62 \\
8 & 12 & 12 & 24 & 36 & 24 & 60 \\
9 & 16 & 4 & 20 & 34 & 26 & 60 \\
10 & 18 & 6 & 24 & 34 & 24 & 58 \\
11 & 12 & 10 & 22 & 34 & 22 & 56 \\
12 & 20 & 10 & 30 & 34 & 22 & 56 \\
13 & 8 & 10 & 18 & 28 & 26 & 54 \\
14 & 10 & 10 & 20 & 28 & 24 & 52 \\
15 & 12 & 10 & 22 & 28 & 22 & 50 \\
16 & 14 & 10 & 24 & 28 & 20 & 48 \\
17 & 10 & 2 & 12 & 24 & 24 & 48 \\
18 & 14 & 6 & 20 & 26 & 22 & 28 \\
19 & 4 & 8 & 12 & 20 & 26 & 46 \\
20 & 14 & 12 & 26 & 18 & 28 & 46 \\
21 & 16 & 12 & 28 & 18 & 26 & 44 \\
22 & 12 & 10 & 22 & 22 & 18 & 40 \\
23 & 10 & 16 & 26 & 20 & 16 & 36 \\
$\mathbf{T S}$ & $\mathbf{3 1 0}$ & $\mathbf{2 1 4}$ & $\mathbf{5 2 4}$ & $\mathbf{6 9 6}$ & $\mathbf{5 5 4}$ & $\mathbf{1 2 5 0}$ \\
\hline
\end{tabular}

Table 2. The menan, standard deviation and other measures of central tendency of the beginning subjects' correct responses in the pre- and post-tests.

\begin{tabular}{lllllll}
\hline & Pre-Test & \multicolumn{5}{l}{ Post-Test } \\
\cline { 2 - 7 } & Part A & Part B & Total & Part A & Part B & Total \\
\hline Mean & 13.48 & 9.30 & 22.78 & 30.26 & 24.09 & 54.35 \\
Mode & 14 & 10 & 22 & 36 & 28 & 64 \\
Median & 20 & 10 & 22 & 34 & 24 & 56 \\
Standard & 4.14 & 3.62 & 5.13 & 6.11 & 3.01 & 8.54 \\
Deviation & & & & & & \\
\hline
\end{tabular}

Table 3. T-Test

\begin{tabular}{llllll}
\hline & Means & & SD & T \\
\cline { 1 - 4 } Variables & Pre-test & Post-test & Pre-test & Post-test & \\
\cline { 1 - 5 } Part (A) & 13.48 & 30.26 & 4.14 & 6.11 & $10.66^{*}$ \\
Part (B) & 9.30 & 24.09 & 3.62 & 3.51 & $13.76^{*}$ \\
Total Score & 22.76 & 54.35 & 5.13 & 8.54 & $14.86^{*}$ \\
\hline
\end{tabular}

*Statistically significant at 0.01 . 
The following figures illustrates the increase in the number of correct responses made by the begining subjects int he listenign comprehension test (Parts A and B).

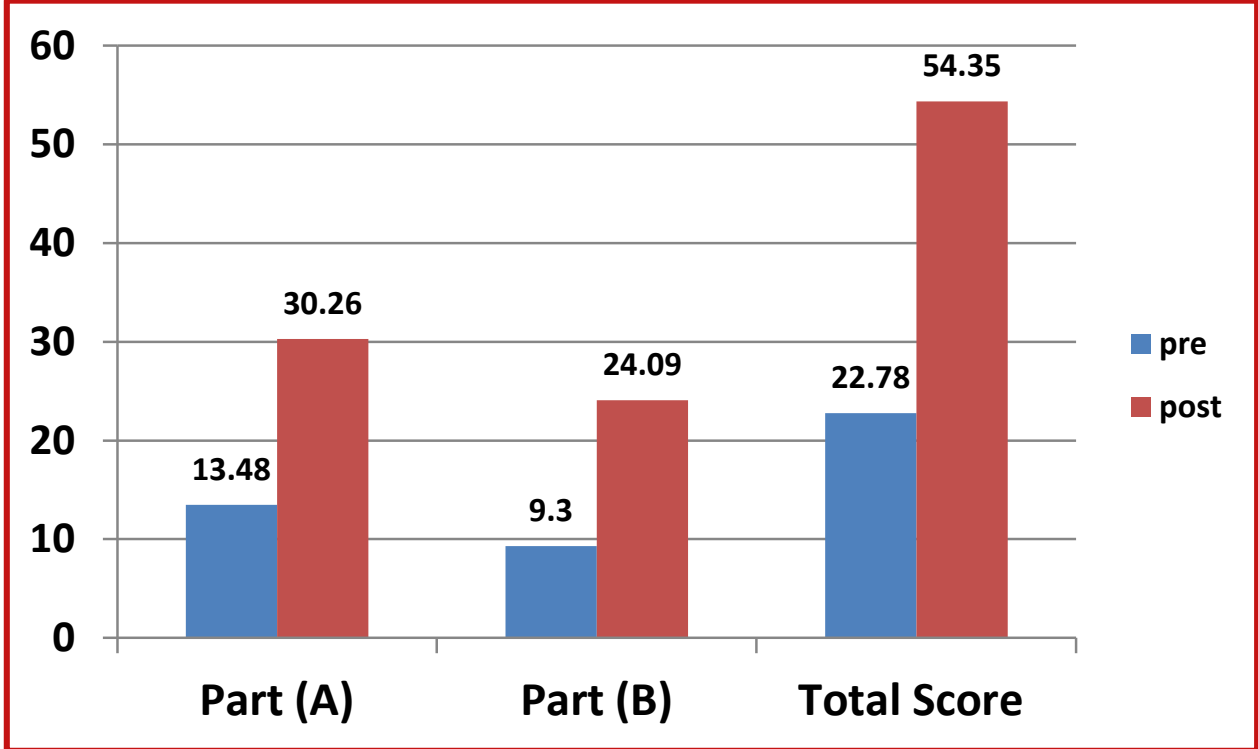

Figure 1. Plot of the beginning subjects' correct responses in Part (A) and (B) of the listening test.

Table 4. Achievement of the advanced subjects in the pre- and post-test of the listening comprehension.

\begin{tabular}{lllllll}
\hline & Pre-Test & & \multicolumn{5}{l}{ Post-Test } \\
\cline { 2 - 7 } & Part A & Part B & Total & Part A & Part B & Total \\
& $\mathbf{( 4 0 )}$ & $\mathbf{( 3 0 )}$ & $\mathbf{( 7 0 )}$ & $\mathbf{( 4 0 )}$ & $\mathbf{( 3 0 )}$ & $\mathbf{( 7 0 )}$ \\
\hline 1 & 32 & 22 & 54 & 38 & 28 & 66 \\
2 & 30 & 22 & 52 & 38 & 26 & 64 \\
3 & 22 & 20 & 42 & 36 & 28 & 64 \\
4 & 22 & 10 & 32 & 38 & 26 & 64 \\
5 & 16 & 12 & 28 & 36 & 28 & 64 \\
6 & 16 & 12 & 28 & 38 & 28 & 64 \\
7 & 28 & 20 & 48 & 36 & 26 & 62 \\
8 & 22 & 18 & 40 & 36 & 26 & 62 \\
9 & 22 & 10 & 32 & 40 & 22 & 62 \\
10 & 24 & 20 & 44 & 36 & 22 & 58 \\
11 & 24 & 18 & 42 & 32 & 24 & 56 \\
12 & 20 & 20 & 40 & 32 & 24 & 56 \\
13 & 22 & 16 & 38 & 32 & 24 & 56 \\
14 & 20 & 18 & 38 & 26 & 28 & 54 \\
15 & 16 & 16 & 32 & 30 & 22 & 52 \\
16 & 12 & 10 & 22 & 32 & 20 & 52 \\
17 & 26 & 12 & 38 & 32 & 18 & 50 \\
18 & 14 & 20 & 34 & 28 & 22 & 50 \\
19 & 24 & 20 & 44 & 32 & 14 & 46 \\
20 & 18 & 14 & 32 & 30 & 16 & 46 \\
21 & 18 & 10 & 28 & 28 & 16 & 44 \\
22 & 16 & 18 & 43 & 22 & 18 & 40 \\
23 & 12 & 12 & 24 & 18 & 10 & 28 \\
TS & $\mathbf{4 7 6}$ & $\mathbf{3 7 0}$ & $\mathbf{8 4 6}$ & $\mathbf{7 4 4}$ & $\mathbf{5 1 6}$ & $\mathbf{1 2 6 0}$ \\
\hline & & & & & & \\
Published by Sciedu & Press & & 29 & & ISSN $1927-6028$ & E-ISSN-6036
\end{tabular}


Table 5. The mean, standard deviation and other measures of central tendency of the beginning subjects' correct responses in the pre- and post-tests

\begin{tabular}{|c|c|c|c|c|c|c|c|}
\hline & \multicolumn{4}{|l|}{ Pre-Test } & \multicolumn{3}{|c|}{ Post-Test } \\
\hline & Part A & Part B & Total & & Part A & Part B & Total \\
\hline Mean & 20.70 & 16.09 & 36.78 & & 32.35 & 22.44 & 54.78 \\
\hline Mode & 22 & 20 & 32 & & 32 & 28 & 64 \\
\hline Median & 22 & 18 & 38 & & 32 & 24 & 56 \\
\hline $\begin{array}{l}\text { Standard } \\
\text { Deviation }\end{array}$ & 5.26 & 4.15 & 8.23 & & 5.26 & 4.97 & 9.30 \\
\hline \multicolumn{8}{|c|}{ Table 6. T-Test } \\
\hline & \multicolumn{2}{|l|}{ Means } & \multicolumn{3}{|c|}{ SD } & & \multirow[t]{2}{*}{$\mathbf{T}$} \\
\hline Variables & Pre-test & Post-test & \multicolumn{3}{|c|}{ Pre-test } & Post-test & \\
\hline Part (A) & 20.70 & 32.35 & & 5.26 & & 5.26 & $7.35^{*}$ \\
\hline Part (B) & 16.09 & 22.44 & & 4.15 & & 4.97 & $4.60 *$ \\
\hline Total Score & 36.78 & 54.78 & & 8.23 & & 9.30 & 6.80 \\
\hline
\end{tabular}

$*$ Statistically significant at 0.01 .

The following figures illustrates the increase in the number of correct responses made by the subjects in the listening Advanced comprehension test (Parts A and B).

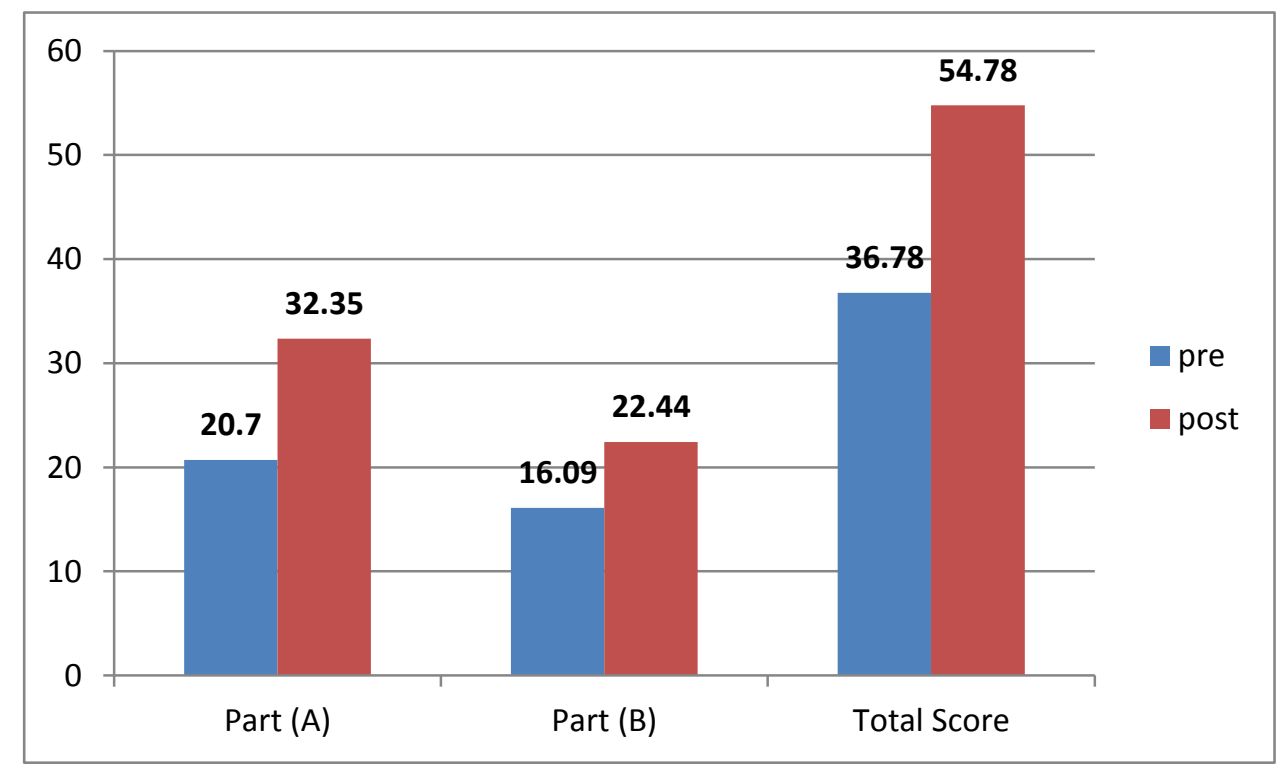

Figure 2. Plot of the advanced subjects' correct responses in Part (A) and (B) of the listening test. 


\section{Appendix (2)}

\section{Section I: Listening Comprehension}

\section{Part A:}

There are twenty statements, and twenty questions on them. The statement will be spoken by the voice on the tape only once. It can't be repeated. There are four sentences for each question on the statement. Listen carefully to the statement, then choose the one sentence which is closest in meaning to the statement you have heard. Blacken the letter of the correct answer. The voice on the tape will say "question number one..." and will read the statement. There will be a pause of about fifteen seconds for you to choose the answer. Then the voice will go (In to say: "question number two". If you listen carefully and understand the statement, fifteen seconds will be enough to read the four sentences and decide which is the correct one and mark it on the answer sheet.

\section{Part A: Questions}

1. (a) He only comes here on special days.

(b) He comes here from time to time.

(c) He frequently drives here.

(d) He seldom comes here.

2. (a) Ali wants to change the house into a store

(b) He wants to renovate and fix it up.

(c) He wants to give it back to its owner.

(d) He wants to sell it.

3. (a) School is starting early this year.

(b) School usually begins in September.

(c) School usually begins in October.

(d) School never begins in November.

4. (a) Now, it is warmer than it was yesterday

(b) The temperature is ten degrees.

(c) The thermometer is broken because it was dropped.

(d) It is colder now than it was yesterday.

5. (a) Lena now earns $\$ 18.000$ a year.

(b) She always earned $\$ 1200$ last month

(c) She always earns $\$ 1500$ a month.

(d) Lena earned \$ 1500 last month

6. (a) Danny failed the test and was sad.

(b) He was happy to hear the good result.

(c) Danny's score made him nervous.

(d) Danny is nervous because he will sit for the test. 
7. (a) Samir boarded The train early.

(b) He carried a board with him onto the train.

(c) The train left an hour earlier.

(d) Samir did not catch the train.

8. (a) She bought a steak.

(b) She ordered a hotdog.

(c) She always finds what she wants.

(d) Mary wishes to buy a hotdog at the beginning.

9. (a) Raji invited his sister to gruel.

(b) Raji was always a loving brother.

(c) Raji was an unforgiving brother for a long time.

(d) Raji attended a wedding ceremony with his sister.

10. (a) They usually go by bus to work.

(b) They seldom drive to work.

(c) Under normal circumstances they drive to work.

(d) They must drive in order to get to work.

11. (a) The speaker is in a grocery shop.

(b) $\mathrm{He}$ is in church.

(c) He is in a dentist's clinic.

(d) He is in a barber's shop.

12. (a) He is always late.

(b) He leaves an hour before he is due.

(c) He is always early.

(d) He leaves for work just before he is due.

13. (a) I can spend more than twenty dollars.

(b) I can't spend twenty dollars.

(c) I don't have to spend twenty dollars.

(d) I can't spend less than twenty dollars.

14. (a) I wish I could take another plane.

(b) I can't come because I have a previous engagement.

(c) I wish they could come.

(d) I wish they could take the other plane. 
15. (a) They did not like the meal.

(b) They were invited but they reclined.

(c) The meal was tasty, so they enjoyed it very much.

(d) The meat was no good.

16. (a) She can't stand while I am eating.

(b) She likes steak while I am not standing.

(c) You can't eat when you have a stick.

(d) She dislikes steak.

17. (a) I didn't hear you well. Repeat what you said.

(b) Say that again.

(c) I accept your idea.

(d) Don't say that again.

18. (a) We are eager to visit you soon.

(b) We are looking for you.

(c) We were looking for more words.

(d) We have seen you many times formerly

19. (a) I am trying hard to buy an apartment.

(b) I am crying of headache in my apartment.

(c) I am trying hard looking for an apartment to rent.

(d) I am going out to search for an apartment.

20. (a) I shall buy a house soon.

(b) I couldn't buy the house.

(c) I can't buy the house now.

(d) I will not buy the house even if I have the money.

\section{Part B:}

You will hear fifteen short conversations between two speakers. At the end of each conversation, a third voice will ask a question about what was said. Read the four possible answers and choose the best answer to the question you have heard. On the answer sheet blacken the letter of the correct answer.

21. (a) at home.

(b) in the hospital.

(c) at work.

(d) at the store.

22. (a) She is going to earn more money.

(b) She's writing a book. 
(c) She's enjoying reading good books.

(d) She's met some interesting students.

23. (a) At a department store

(b) In an airport.

(c) At the post office.

(d) At the life insurance office.

24. (a) Looking for a new job.

(b) Starting her vacation.

(c) Quitting her job.

(d) Complaining to her neighbour.

25. (a) He enjoys it.

(b) $\mathrm{He}$ is indifferent towards it.

(c) He dislikes it.

(d) He minds overtime work.

26. (a) One

(b) Four

(c) Three

(d) Two

27. (a) 7:00

(b) $7: 30$

(c) $7: 45$

(d) $8: 00$

28. (a) Being away from home.

(b) Being away for a long time.

(c) Any kind of boats.

(d) Activities on the water.

29. (a) Away to the lake.

(b) On a picnic in the woods.

(c) To the beach.

(d) Skiing.

30. (a) Over six feet tall.

(b) Shorter than she is.

(c) Five feet eight inches.

(d) Less than six feet tall. 
31. (a) Father and daughter

(b) Doctor and patient.

(c) Customer and receptionist.

(d) Athlete and coach.

32. (a) Bus driver.

(b) Social worker.

(c) Airline hostess.

(d) Travel agent

33. (a) Clean the rooms.

(b) Wash the car.

(c) Exercise in the sun.

(d) None of these.

34. (a) It is always rewarding.

(b) It is fine because the payment and the circumstances are good.

(c) It is not good under any circumstances.

(d) One must keep looking for a better job.

35. (a) She thinks Hala is stupid.

(b) She thinks Hala is a thief.

(c) She thinks Hala is honest, but liable to make a mistake.

(d) She is ashamed of Hala.

\section{Transcripts for Listenign Comprehension Section}

\section{Part A:}

Directions: For each problem you will hear short statement which will be spoken once only. Listen carefully when you here a statement, read the four sentences in your test book and decide which one is closest in meaning to the statement you have heard. Then blacken the letter of the answer you have chosen on your answer sheet.

\section{Questions:}

1. He drives here on occasion.

2. Ali bought an old house in order to restore it.

3. I am surprised! It's October and we haven't started school yet.

4. The temperature has dropped ten degrees today.

5. Lena got a raise this month. Now she makes $\$ 1500$ a month.

6. Danny breathed a sigh of relief when he heard of his success.

7. Samir boarded the train half an hour before it was supposed to depart.

8. Mary wanted to buy a steak, but she settled for a hot dog.

9. Raji held a grudge against his sister for years.

10. Their car broke down, so they took the bus to work. 
11. I'll get my hair cut while I am here.

12. It takes him an hour to get to school in the morning.

13. I have to spend less; twenty dollars is too much.

14. I wish I could make it, but really I have other plans.

15. They have never eaten such a delicious meal.

16. She can't stand eating steak.

17. You can say that again.

18. We are looking forward to visiting you.

19. I'm going out of my head trying to find an apartment to lease.

20. If I had enough money, I would buy the house.

\section{Part B:}

In this part you will have fifteen short conversations between two speakers. At the end of each conversation a third voice will ask a question about what was said. The conversation and the question will be spoken only one time. After hearing the conversation and the question about it, read the four possible answers and choose the correct answer to the question you have heard. Then blacken the letter of the correct answer on your answer sheet.

21. Woman's voice: How is your father feeling now? Man's voice: He is better, thanks. He should be back home in few days. The operation was successful and the doctor says he'll recover soon.

Third voice: Where is his father now?

22. Man's voice: It seems you really enjoy your literature class.

Woman's voice: Surely I do. It's opened new world for me.

I'm acquainted with some of the world's famous writers.

Third voice: Why is she so excited?

23. Woman's voice: This parcel is going to Los Angeles. I want to insure it for $\$ 25.00$.

Man's voice: Ok. That will be $\$ 3.50$ postage and $\$ 21.50$ for the insurance.

Third voice: Where is the conversation taking place?

24. Man's voice: Did you tell Mrs. Johnson that you are looking for another job?

Woman's voice: No, not yet. If I didn't find one, I'll stay here for few months.

Third voice: What is the woman doing?

25. Woman's voice: you have a lot of work at your office. You always stay late and work overtime.

Man's voice: That is true, but it doesn't bother me. The work is interesting. I don't mind the extra hours.

Third voice: How does the man feel about his job?

26. Man's voice: Sara is enthusiastic about her ballet class, isn't she?

Woman's voice: Yes, she used to take lessons only two days a week, but now she goes every other day: Friday, Monday, and Wednesday.

Third voice: How many days does Sara take ballet lessons? 
27. Woman's voice: What time does your bus leave for the office in the morning?

Man's voice: It is an on no regular schedule. On Mondays it leaves at 7:15; on Tuesdays and Wednesdays it leaves fifteen minutes later; and on Thursdays and Fridays it leaves forty five minutes later.

Third voice: What time does the bus leave on Fridays?

28. Man's voice: I'd like to go sailing, but sometimes I get scared on the water. How long would we be out? Woman's voice: Not too long. We'll be close to the shore. Third voice: What is the man afraid of?

29. Woman's voice: Did you prepare everything?

Man's voice: Yes, I got the bathing suits, some towels, the suntan lotion and two novels.

Third voice: Where are they going?

30. Man's voice: Why won't your sister go out with James. He's five feet eight inches?

Woman's voice: To her, he's still short.

Third voice: The sister prefers dating men who are

31. Woman's voice: I had a bad start in the last race. It was hard to catch up. All I could see was the backs of the other's heads.

Man's voice: The most important thing is concentration. Third voice: What is the relation between the two people?

32. Man's voice: Why did you take this job?

Woman's voice: Really, I didn't know; but I wanted to travel. Man's voice: What are the advantages of the job? Woman's voice: Freedom! With an airline you have a lot of free time you have no job to do at home.

Third voice: What's the woman's job?

33. Woman's voice: It's too hot today. I was going to wash the car and clean the rooms, but I feel I could not. Man's voice: I agree with you. You should relax in heat like this. Too much effort may make you faint.

Third voice: What will the woman probably do?

34. Man's voice: Did you get the job you applied for? Woman's voice: Yes. It pays more than my old job, and I'll like the people better, as well.

Third voice: How do the woman feel about her new job?

35. Man's voice: Do you think Hala took your bracelet? Woman's voice:Yes, but I think it was a mistake. She's just absent minded.

Third voice: What does the woman think of Hala? 